\title{
Assessing the vulnerability of infrastructure to climate change on the Islands of Samoa
}

\author{
S. H. M. Fakhruddin ${ }^{1}$, M. S. Babel ${ }^{1}$, and A. Kawasaki ${ }^{2}$ \\ ${ }^{1}$ Asian Institute of Technology (AIT), Bangkok, Thailand \\ ${ }^{2}$ Department of Civil Engineering, The University of Tokyo, Tokyo, Japan \\ Correspondence to: S. H. M. Fakhruddi (smfwater@gmail.com) \\ Received: 7 January 2015 - Published in Nat. Hazards Earth Syst. Sci. Discuss.: 12 March 2015 \\ Revised: 31 May 2015 - Accepted: 2 June 2015 - Published: 24 June 2015
}

\begin{abstract}
Pacific Islanders have been exposed to risks associated with climate change. Samoa, as one of the Pacific Islands, is prone to climatic hazards that will likely increase in the coming decades, affecting coastal communities and infrastructure around the islands. Climate models do not predict a reduction of such disaster events in the future in Samoa; indeed, most predict an increase. This paper identifies key infrastructure and their functions and status in order to provide an overall picture of relative vulnerability to climate-related stresses of such infrastructure on the island. By reviewing existing reports as well as holding a series of consultation meetings, a list of critical infrastructure was developed and shared with stakeholders for their consideration. An indicator-based vulnerability model (SIVM) was developed in collaboration with stakeholders to assess the vulnerability of selected infrastructure systems on the Samoan Islands. Damage costs were extracted from the Cyclone Evan recovery needs document. Additionally, data on criticality and capacity to repair damage were collected from stakeholders. Having stakeholder perspectives on these two issues was important because (a) criticality of a given infrastructure could be viewed differently among different stakeholders, and (b) stakeholders were the best available source (in this study) to estimate the capacity to repair non-physical damage to such infrastructure. Analysis of the results suggested a ranking of sectors from the most vulnerable to least vulnerable are: the transportation sector, the power sector, the water supply sector and the sewerage system.
\end{abstract}

\section{Introduction}

Pacific Islanders have been exposed to risks associated with climate change. Instrumental measurements and local observations have recorded changes in temperature and precipitation patterns, sea level, coastal erosion, wind dynamics and the marine environment (Hoegh-Guldberg and Bruno, 2010; IPCC, 2013; Webb and Kench, 2010). Climate change has adversely been affecting the vulnerability of developing economies. Various studies on exposure to vulnerability and reduction of impacts of climate change have been closely analyzed (Burton, 1993; Cannon, 1994; Cannon et al., 2003; Dercon, 2001, 2002, 2006; IPCC, 2007; Moser, 1998; Pelling, 2003; Barnett and Adger, 2007; McCarthy, 2001; Smit, 2003; Eakin and Luers, 2006; Bankoff et al., 2004; Pelling, 2003; Füssel and Klein, 2006; Cutter, 2003; Ionescu et al., 2005; Kasperson et al., 2005). The vulnerability studies shed light on various social and economic factors affecting the societal setup in poor countries (Ibarrarán et al., 2010). The increased frequency of natural hazards due to climate change poses more vulnerability to less equipped countries (Downing, 1991). Therefore, it is crucial to understand the systems affected by climate change, and the implications of current vulnerability to these changes. This enhanced understanding supports the scientific community and policy makers in their efforts to ameliorate such vulnerability (Adger, 1999).

The IPCC (International Panel on Climate Change) explores vulnerability through three core concepts: firstly, exposure magnitude to which a system is physically in harm's way; secondly, the sensitivity of a system i.e., its likelihood to be affected by a shock; and thirdly, the adaptive capacity of a system to cope or adjust with the negative impacts 
of a shock (Barnett and Adger, 2007; McCarthy, 2001; Smit, 2003).

Social vulnerability is defined as the exposure of groups or individuals to stress as a result of social and environmental change, where stress refers to unexpected changes and disruption to livelihoods (Adger, 1999). This definition emphasizes the social dimensions of vulnerability following the tradition of analysis of vulnerability to hazards, food insecurity and as a dimension of entitlements. However, the predominant view depends upon the physical dimensions of vulnerability from the impacts of climate change. A system consisting of indicators is set up to analyze the relative vulnerability of given individuals or a societal setup (Adger, 1999).

A model of social vulnerability to reduce the impacts of climate change involves focus on the social aspects of such events. A model for vulnerability should be based on human welfare aspects, which leads to the environmental changes induced by the climate change gaining significance as and when they have cause and effect on the relative and absolute well-being of individuals and groups; according to O'Keefe et al. (1976), "without people, there is no disaster".

A theory of vulnerability to climate change must also encompass the collective nature of vulnerability of a group or community to the impacts of climate change, involving a complex set of factors, including the institutional arrangements for preparedness for hazards. With greater numbers of social factors involved in collective vulnerability (gender, ethnic and other differentials of vulnerability (Blaikie et al., 1994)), as well as the nature of different climate-related hazards, an exclusive focus on economic and material aspects of vulnerability is misplaced. These diverse aspects determining vulnerability can be conceptualized as a set of entitlements: it is the structure or architecture of these entitlements that underpins both security and vulnerability (Adger and Kelly, 1998; UN/ISDR, 2004; Cardona, 2004; Wisner, 2002; Thywissen, 2006). These potential rights and reciprocal social coping mechanisms and informal social security are fluid and often only exactly determined in times of crisis (Platteau, 1991; Leach, Mearns and Scoones, 1997; Moser, 1998).

The vulnerability of a system is not only a matter of the number of indicators of the system or individuals in a population who are vulnerable through being exposed to stresses associated with environmental change or not having adaptive capacity. Thus, countries suffering higher losses of lives than others equally exposed have a higher relative vulnerability (Dilley, 2005). For example, Venezuela, Afghanistan and Somalia are countries with a high relative vulnerability to floods (UNDP, 2004). According to Birkman (2007) the applicability of relative vulnerability measures worldwide is proved to be possible. There could be radical shifts in the classification of a country's relative vulnerability due to the occurrence of one major disaster event without any changes in the underlying drivers of vulnerability.

\section{Climate vulnerability in Samoa}

Samoa is comprised of two large volcanic islands (Upolu and Savai'i) and several smaller islands with a total land area of approximately $2935 \mathrm{~km}^{2}$. It lies in the southwest Pacific within an exclusive economic zone of $120000 \mathrm{~km}^{2}$ (GoS, 2013b).

Samoa's islands are highly vulnerable to impacts of climate change, such as sea level rise, increased incidence of extreme events including flooding from storm surges and tsunami inundation (SPCR, 2011). According to the World Bank, Samoa is ranked 30th of countries most exposed to three or more hazards. Samoa ranked 51st out of 179 countries in the Global Climate Risk Index 2012 report on countries that suffer most from extreme weather events (GoS, 2013b). Samoa's climate is greatly influenced by the El Niño-Southern Oscillation (ENSO). The El Niño phase of ENSO generally brings dry conditions over the island group. In contrast, La Niña tends to bring wetter conditions. The influence of global warming on Samoa results in more frequent and extreme rainfall events, longer dry spells, consistent drought events, hotter days, rising sea levels, extreme winds and extremely high air and water temperatures (Climate Risk Profile, 2007). A review of historical climate trends for Apia suggests that the daily maximum temperature increased by about $0.7^{\circ} \mathrm{C}$ over the 20th century while the daily minimum temperature increased by $0.2^{\circ} \mathrm{C}$. Average annual precipitation decreased by about $49 \mathrm{~mm}$ over that century (GoS, 2013a). The observed long-term trend in relative sea level for Apia is $5.2 \mathrm{~mm} \mathrm{yr}^{-1}$. But maximum hourly sea level is increasing by approximately $8 \mathrm{~mm} \mathrm{yr}^{-1}$, a rate far in excess of the observed local and global trends in mean sea level. For Apia an hourly sea level of $1.8 \mathrm{~m}$ above mean sea level is currently a 100 -year event. It will likely be at least a four-year event by 2025 . Satellite data indicate that the sea level has risen near Samoa by about $4 \mathrm{~mm}$ per year since 1993 (GoS, 2013a). Samoa's Second National Communication to the United Nations Framework Convention on Climate Change (GoS, 2010) reports the best estimates of longterm, systematic changes in the future climate for Samoa.

Samoa has suffered serious economic shocks caused by natural disasters. Approximately $80 \%$ of the $403 \mathrm{~km}$ coastline is sensitive or highly sensitive to erosion, flooding or landslides. Under the investigations undertaken for the Coastal Infrastructure Management Strategy, some $68 \%$ of Samoa's national coastline of $578 \mathrm{~km}$ was found to be either extremely vulnerable or vulnerable to coastal erosion (GoS, 2007). For example, there were severe cyclones in the successive seasons of 1989-1990 (i.e., Ofa) and 1990-1991 (i.e., Val), in addition to the major Cyclone Evan in 2012, which all caused massive damage to infrastructure and other assets (World Bank, 2010). Cyclone Evan killed at least five people and displaced 4763 people. It destroyed power plants, cutting power and disrupting communication services; it also destroyed buildings and roads, damaged vast swaths of crops 
and caused severe damage and nationwide disruption to water facilities and distribution systems. According to the Post Disaster National Assessment (GoS, 2013b), "The total estimated damage and loss on Cyclone Evan are equivalent to about 28 percent of the total value of goods and services produced in the country in 2011". The value of durable physical assets across all economic and social sectors destroyed by Evan (referred to as damage) is estimated at USD 103.3 million.

Infrastructure vulnerability to climate change is increasing around the world and Samoa is particularly vulnerable. The whole island population is highly vulnerable to different hazards, but groups facing the highest risks are the rural poor in informal settlements, internally displaced people and those living in marginal areas. Transportation, infrastructure, water and tourism are sectors sensitive to climate extremes. The expected damage to infrastructure for selected climate change phenomena, for example high precipitation, cyclones and sea level rise, may result in coastal inundation, flood damage to homes and property, and damage to roads, ports, bridges and other infrastructure. Samoa's National Adaptation Programme of Action (NAPA) identified nine sectors that are highly vulnerable to the adverse impacts of climate change and climate variability, including extreme events. The nine sectors listed from highest to lowest vulnerability are water, agriculture and food security, forestry, health, urban settlements, coastal environments, communities, trade and industry and works transport and infrastructure.

The National Infrastructure Strategic Plan (NISP) outlines the government's priorities and strategic directions for major initiatives in the economic infrastructure sector over the next 5-10 years. In particular, the NISP is closely linked to the Strategy for the Development of Samoa 2008-2012 (SDS). After any disaster, the "building back better" approach is often advocated, but unless an appropriate assessment of future extreme events and a climate-proofing of infrastructure is undertaken, the sustainability of that infrastructure remains at greater risk.

This paper is focused on the vulnerability of infrastructure to coastal hazards. Even though the infrastructure framework involves many aspects, this paper only focuses on the water sector; that is, the physical components of the water sector infrastructure (e.g., buildings, embankments, bridges, water supplies and sanitation) and the "soft" components (i.e., early warning systems, community preparedness). The general concept of vulnerability can be analyzed in three main categories: physical, systemic and organizational/social.

This paper identifies vulnerabilities for key water-related infrastructure. A method has been adopted for the following three tasks: assessing the climate-related vulnerability of four public infrastructure sectors in Samoa (i.e., water supply, sewerage, land transport and power supply), providing an inventory of critical infrastructure for each sector and ranking those infrastructure systems in terms of their relative vulnerability to climate-related hazards. The vulnerabil- ity assessment used the damage caused by Cyclone Evan as a baseline proxy. Information on the damage to infrastructure was readily available from a study conducted by GoS (2013a). Interviews were conducted with key stakeholders to identify ongoing initiatives, current gaps in the system and possible adaptation options that could be carried out in the project.

\section{Methodology}

This section outlines the methods implemented to assess the vulnerability of public infrastructure systems and the wellbeing of residents of Samoa to the hazards discussed in the previous section.

The Sydney Environmental Vulnerability Assessment (SEVA) framework was recently developed (Tonmoy and ElZein, 2013; Tonmoy et al., 2012) and applied to assess the vulnerability to sea level rise (SLR) of the public infrastructure systems of Shoalhaven City Council in Sydney. It was developed specifically for assessing the vulnerability of infrastructure systems and their users to SLR at a local scale, but can be used for any climate-related hazard. It is an approach where an indicator-based vulnerability model is developed in collaboration with the stakeholders. Involvement of local stakeholders is crucial in order to ensure that the exercise captures the most relevant local contexts. The main objective of this model is to rank a given set of infrastructure sector indicators based on their climate-related vulnerability. Once the model is developed, the overall vulnerability index is developed by aggregating the indicators using one of the mathematical procedures discussed in the following sections. The following section describes the indicator-based vulnerability model developed for this study, its development process and the mathematical approach used for aggregation of the developed model.

A participatory approach was used to develop the vulnerability model, as it is essential to engage with local stakeholders to ensure that the most relevant local contexts are captured in the model. Two missions were conducted with the local stakeholders to identify needs and requirements. A detailed step-by-step process of the whole exercise is shown in Fig. 1.

The process flow diagram, shown in Fig. 1, demonstrates the process of assessing the vulnerabilities of infrastructure used in this paper. The assessment started with preliminary discussions with local experts regarding their organizational goal, objectives and existing methods used in the study. After reviewing previously conducted hazard studies of Samoa and other relevant literature, a conceptual model of Samoa's vulnerability was developed. Following this conceptual model, a list of vulnerability indicators was proposed to the stakeholders for further consultation (first phase of consultation), who then selected those that are most relevant in the context of Samoa. Starting from the IPCC definition of vulnerability, 


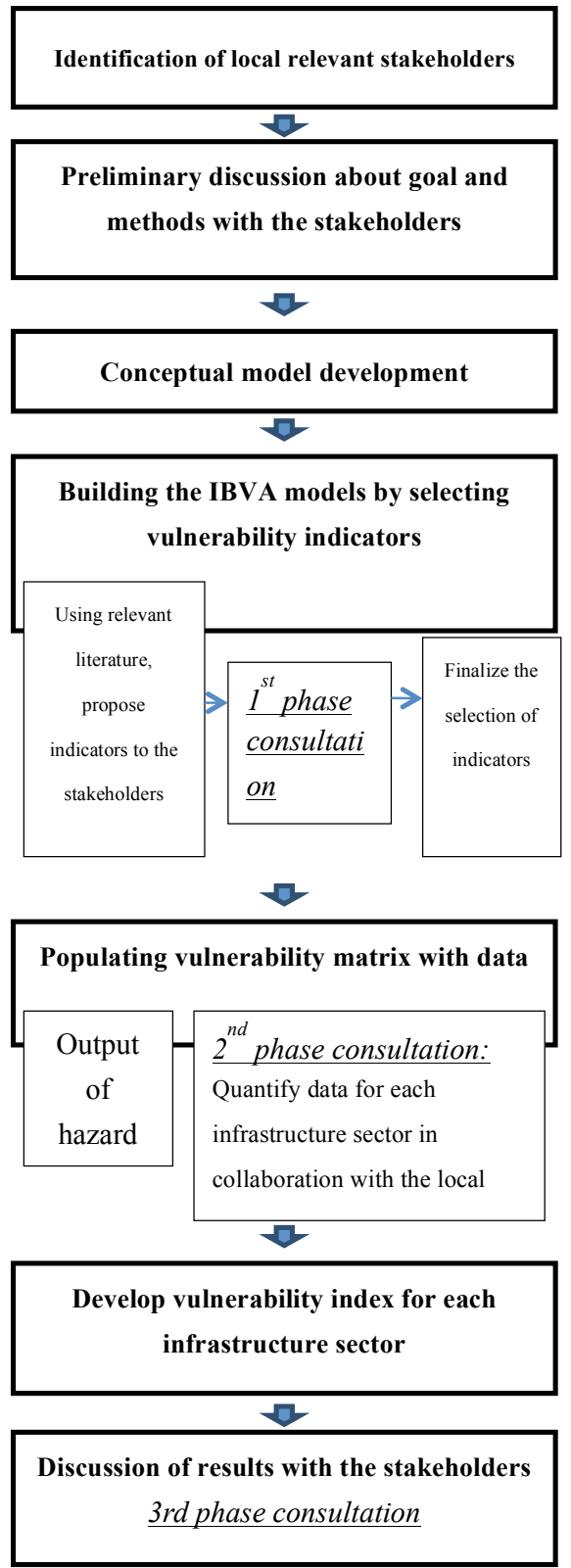

Figure 1. Stakeholder consultation and information flow process.

the Samoan Infrastructure Vulnerability Model (SIVM) was developed with a focus on the vulnerability of the infrastructure systems of Samoa to climate-related hazards, by considering the biophysical, socio-economic and institutional dimension of risk.

In order to select the most relevant set of indicators for Samoa from the proposed set, the following stakeholders were identified and consulted in the first mission: Planning and Urban Management Agency (PUMA) for water supply and sanitation, Land Transport Authority (LTA) for transportation and drainage, Electric Power Corporation (EPC) for power supply authority, Meteorological Department and

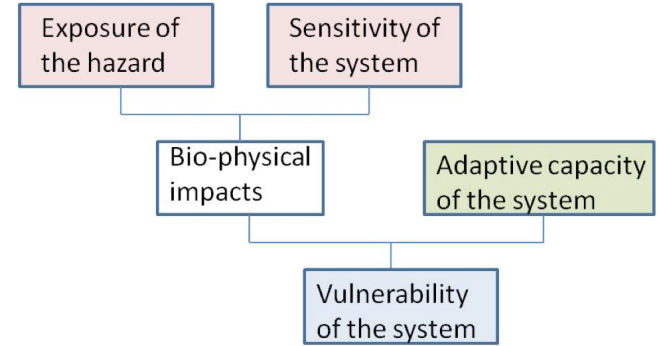

Figure 2. Components of vulnerability (adopted from IPCC, 2001).

Water Resources for early warning system for extreme climate events and the Ministry of Works, Transport and Infrastructure for the "building back better" approach and building codes. The details of the stakeholders interviewed are summarized in Table A1.

Once the indicators of the model were finalized, the scores for each indicator of each infrastructure system were estimated in order to populate the vulnerability matrix. This was done in collaboration with the engineers and experts from the respective departments previously identified (second phase of the consultation). A third phase of consultation may be required after development of this vulnerability index in order to discuss the results with the stakeholders and to identify whether it differs from their local perception of their vulnerability. The following sections describe the conceptual model as well as the indicators that were finally selected.

\subsection{Conceptual model}

One commonly used definition of vulnerability (illustrated in Fig. 2) was presented by the IPCC in its Third Assessment Report (IPCC, 2001), which was adopted for the Samoan context as well:

"[Vulnerability is] the degree to which a system is susceptible to, or unable to cope with, adverse effects of climate change, including climate variability and extremes. Vulnerability is a function of the character, magnitude, and rate of climate variation to which a system is exposed, its sensitivity, and its adaptive capacity" (McCarthy et al., 2001).

A general conceptual model of an infrastructure sector of the Samoan Islands followed from this and is shown in Fig. 3. Climatic events (e.g., storm surge, flooding and inundation) pose certain hazards in Samoa (referred to as "climate forcing"). The impact depends on the characteristics of the infrastructure (e.g., geographic location, physical integrity). The social, institutional and financial resources that the community has access to are a reflection of its adaptive capacity.

For this vulnerability model, a given infrastructure system (e.g., water supply, transportation) is taken as a socioecological system which needs to be ranked. A plausible cyclone with intensity equivalent to Cyclone Evan is considered as the hazard. The physical integrity of the public infrastructure of a given sector and the well-being of its users were 
Table 1. Vulnerability indicators of SIVM.

\begin{tabular}{|c|c|c|c|c|c|c|}
\hline Dimension & ID & Indicator & Unit & Type & $D_{\mathrm{a}}$ & Data source \\
\hline Exposure & V1 & $\begin{array}{l}\text { Reported damage of the infrastructure } \\
\text { during Cyclone Evan }\end{array}$ & $\$$ & Quantitative & + & $\begin{array}{l}\text { Study conducted by } \\
\text { (GoS 2013a) }\end{array}$ \\
\hline Sensitivity & $\mathrm{V} 2$ & $\begin{array}{l}\text { Criticality of the service that } \\
\text { the infrastructure provides }\end{array}$ & $\mathrm{n} / \mathrm{a}$ & Semi-quantitative & + & $\begin{array}{l}\text { Stakeholder input through } \\
\text { expert estimation }\end{array}$ \\
\hline Adaptive capacity & V3 & $\begin{array}{l}\text { At current situation, capacity of the service providing } \\
\text { authority to repair the infrastructure if damaged }\end{array}$ & $\mathrm{n} / \mathrm{a}$ & Semi-quantitative & - & $\begin{array}{l}\text { Stakeholder input through } \\
\text { expert estimation }\end{array}$ \\
\hline
\end{tabular}

where $D_{\mathrm{a}}$ denotes direction; + (-) indicates that vulnerability increases (decreases) with increasing indicator.

$\mathrm{n} / \mathrm{a}$ denotes not applicable.

Table 2. Scales used for V2 for all infrastructure systems.

\begin{tabular}{lc}
\hline Description & Scale \\
\hline $\begin{array}{l}\text { Extremely critical - asset failure is unacceptable. The consequences are so } \\
\text { serious that they cannot be tolerated under any circumstances }\end{array}$ & 3 \\
Critical - the consequences of failure may be tolerated, provided & 2 \\
the risk of failure is as low as reasonably practicable & \\
Non-critical - consequences of asset failure are acceptable & 1 \\
No infrastructure affected & 0 \\
\hline
\end{tabular}

Table 3. Scales used for V3 for all infrastructure systems.

\begin{tabular}{lc}
\hline Description & Scale \\
\hline Full capacity to repair & 3 \\
Partial capacity to repair & 2 \\
Cannot repair with existing capacity & 1 \\
\hline
\end{tabular}

considered as the valued attribute of concern. The vulnerability of the users of a given infrastructure is partly determined by the extent to which the service it provides is critical, along with the ability of the service-providing authority and/or the users to deploy an alternative to the disrupted service. The overall infrastructure vulnerability was determined by the physical impact on its infrastructure and the sensitivity of its users to the impacts, minus the capacity of the authority and individuals to cope with those impacts.

\subsection{Selecting indicators}

Following the definition of the model parameters, indicators were identified through which SIVM could be made operational, i.e., used as a basis for ranking vulnerabilities of the infrastructure system. The selection was conducted in collaboration with government experts from Samoa.

First, reported damage of the infrastructure during $\mathrm{Cy}-$ clone Evan is taken as an indicator of physical exposure of the infrastructure to a climatic hazard (V1). Second, the sensitivity of users of a given infrastructure was captured by expert and stakeholder judgment about the degree to which the disrupted service is critical, i.e., the extent to which it serves a vital function (e.g., from the user's point of view the water supply may be more vital than sanitation) (V2). Finally,

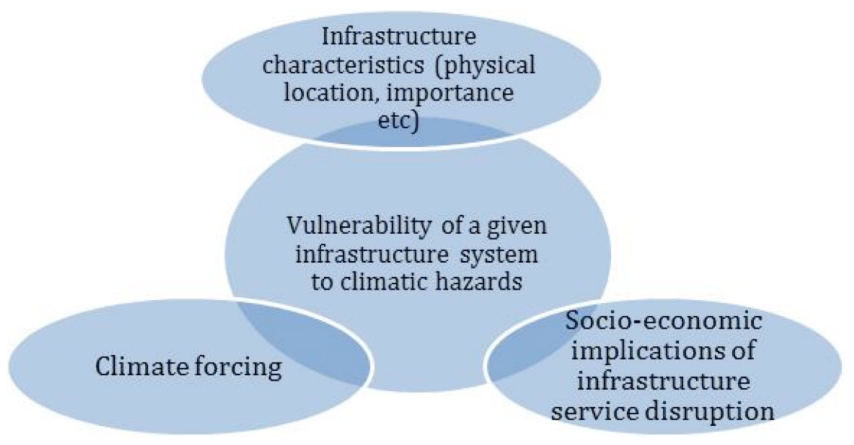

Figure 3. Vulnerability model.

adaptive capacity in this case is reflected by the capacity of the local authority to repair the infrastructure after a possible disruption (V3). The vulnerability indicators of SIVM and scales used for eliciting experts' and stakeholders' judgment for V2 and V3 are shown in Tables 1-3.

The infrastructure systems of Samoa were divided into two categories: hard infrastructure (consisting of water supply, sewerage, land transport infrastructure and power supply infrastructure) and soft infrastructure (consisting of early warning systems and knowledge development programs). Only hard infrastructure components were considered in this study. Any design of infrastructure related to the hydrologic cycle (e.g., levees, embankments, bridge, roads) is based on an underlying assumption that the probability distribution of extreme weather is statistically stationary. This assumption is called into question by climate change, resulting in uncertainty about the future performance of systems constructed under this paradigm. In the context of climate change, the stationary hypothesis represents the biggest challenge for the 
Table 4. Infrastructure needs assessment by stakeholders.

\begin{tabular}{|c|c|}
\hline Infrastructure & Needs assessment \\
\hline Housing and land use & $\begin{array}{l}\text { - Flood hazard zoning and construction of new houses in the safe area. } \\
\text { - Demonstration of the "building back better" approach with climate-proof housing. }\end{array}$ \\
\hline Land transport & $\begin{array}{l}\text { - Improvement of storm water drainage system to reduce flooding behind roads } \\
\text { - Construction and retrofitting of damaged bridges } \\
\text { - Construction of roads }\end{array}$ \\
\hline Water & $\begin{array}{l}\text { - Development of flood forecasting system for Vaisigano river basin and other river basins as well. } \\
\text { - End-to-end early warning mechanism for flood events } \\
\text { - Rainwater harvesting at family and community levels } \\
\text { - Routing the drainage system far from the water source and supply } \\
\text { systems and other essential, sensitive infrastructures. } \\
\text { - Sensitization to people in the community about the efficient use of water }\end{array}$ \\
\hline Sanitation and water supply & $\begin{array}{l}\text { - Support sanitation service to rural populations } \\
\text { - Promotion of drinking water } \\
\text { - Treatment system at household level as the point of use (POU) options } \\
\text { - Education and awareness program about the diarrheal and other water-borne diseases }\end{array}$ \\
\hline Electricity & $\begin{array}{l}\text { - The electricity networks can be passed through underground system } \\
\text { so that the overtopping of sea water does not affect them } \\
\text { - Relocation of main supply system from the coastal hazard zones } \\
\text { - Detail assessment of the risk of hydro-power } \\
\text { stations and rebuild climate proof supply network. }\end{array}$ \\
\hline
\end{tabular}

present and the future of infrastructure design. "Climatesmart" or "climate-proof" infrastructure has been suggested, which should be designed based on several scenarios of future climate change and vulnerability assessments at the community level. Based on the consultations with the stakeholders, some of the needs that were identified are summarized in Table 4.

\subsection{Modeling and aggregation of indicators}

The aggregation of indicators brings together the overall picture of the vulnerability of the system. Additive, weightbased aggregation was adopted in this study. This approach is used widely in literature for vulnerability studies (Babel et al., 2011; Ebert and Welsch, 2004; Gbetibouo et al., 2010; Moss, 2001; Preston et al., 2008).

$V_{m}=\sum_{i=1}^{n} W_{i} \bar{I}_{m i}$

Here, $V_{m}$ is the vulnerability of a given infrastructure system $(m), n$ is the number of indicators of the vulnerability model, $w_{i}$ is the weight of importance of a given indicator $i$ and $\bar{I}_{m i}$ is the normalized indicator. Normalization is required for bringing different types of indicator data into a common platform where they can be aggregated. There are different techniques of normalization available in literature. In this study, the following approach was used for normalization.

$\bar{I}_{m i}=\frac{\left(I_{m i}-I_{i, \min }\right) * 100}{I_{i, \max }-I_{i, \min }}$

Here, $I_{m i}$ is the $(i)$ indicator of the $m^{t h}$ infrastructure system; $I_{i, \min }=\min \left(I_{m i}\right)$ and $I_{i, \max }=\max \left(I_{m i}\right)$.

\section{Results}

Table 5 shows the values of the indicators of the SIVM for each of the infrastructure components that were collected for the sources mentioned in Table 1. One of the objectives of this study was to assess relative vulnerability of the infrastructure systems of Samoa. In order to achieve that, vulnerability indices were developed using the methods stated in the previous section (Table 7). It should be noted that vulnerability indices were created for the whole infrastructure system only, not for individual infrastructure components. For V1, collected damage data of different infrastructure components of a given infrastructure system were summed to get the total reported damage of the sector. V2 and V3 are ordinal variables; therefore, values of all infrastructure components of a system were averaged to get the representative value of the system (e.g., the average of all V2 of the 20 components of the water supply system was taken as the V2 of the water supply system; see Table 6). These values were then normalized and converted into indices using the Eqs. (1) and (2). In the case of V3 (which is lower, the more vulnerable), $100-\bar{I}_{m i}$ 
S. H. M. Fakhruddi et al.: Assessing the vulnerability of infrastructure to climate change on the Islands of Samoa 1349

Table 5. Vulnerability raw data based on stakeholders, weighted.

\begin{tabular}{|c|c|c|c|c|}
\hline & & \multicolumn{3}{|c|}{ Vulnerability indicators } \\
\hline & & $\mathrm{V} 1$ & $\mathrm{~V} 2$ & V3 \\
\hline & & $\begin{array}{l}\text { Extent of damage } \\
\text { in Cyclone Evan (USD) }\end{array}$ & $\begin{array}{l}\text { Criticality of the } \\
\text { service (based on a } \\
\text { predefined scale) }\end{array}$ & $\begin{array}{l}\text { Capacity of the service } \\
\text { providing authority to } \\
\text { repair damaged infrastructure }\end{array}$ \\
\hline & Weight of indicator & 1 & 1 & 1 \\
\hline Infrastructure system & Infrastructure node & & & \\
\hline \multirow{24}{*}{ Water supply } & Afiamalu & 1167 & 2 & 2 \\
\hline & Malololelei & 448659 & 2 & 2 \\
\hline & Vailima & 5852 & 2 & 2 \\
\hline & Alaoa & 2331690 & 3 & 2 \\
\hline & Maagiagi & 219956 & 2 & 2 \\
\hline & Vaivase-Uta & 758 & 2 & 2 \\
\hline & Fagalii- Uta & 197 & 2 & 2 \\
\hline & Vailele & 921 & 2 & 2 \\
\hline & Tapatapao & 8604 & 2 & 2 \\
\hline & Fuluasou JR & 62982 & 2 & 2 \\
\hline & Fuluasou EU & 12800 & 2 & 2 \\
\hline & Aleisa & - & 2 & 2 \\
\hline & Lefaga & 21930 & 2 & 2 \\
\hline & Tafitoala and Tiavi & 578513 & 3 & 2 \\
\hline & Togitogiga & 8772 & 2 & 2 \\
\hline & Piu & - & 2 & 2 \\
\hline & Lepa & - & 2 & 2 \\
\hline & Lano & 1316 & 2 & 2 \\
\hline & Aleipata & 3026 & 2 & 2 \\
\hline & Faleapuna & 1272 & 2 & 2 \\
\hline & Total damage/avg criticality and capacity & 3708415 & 2.1 & 2.0 \\
\hline & 5040 number of damaged on-site sanitation facility & 4290000 & 3 & 1 \\
\hline & SWA sewerage system & 39474 & 3 & 1 \\
\hline & Total damage/avg criticality and capacity & 4329474 & 3 & 1 \\
\hline \multirow{12}{*}{ Power supply } & Power generation & & & \\
\hline & Samasoni hydro power plant & 7894737 & 2 & 1 \\
\hline & Alaoa hydro power plant & 910658 & 2 & 1 \\
\hline & Fale ole Fee hydro power plant & 5166930 & 1 & 1 \\
\hline & Lalomauga hydro power plant & 287939 & 1 & 1 \\
\hline & Taelefaga hydro power plant & 126228 & 1 & 1 \\
\hline & Tanugamanono diesel thermal plants & 730263 & 1 & 1 \\
\hline & Savai'i diesel thermal plants & 28509 & 1 & 1 \\
\hline & Transmission and distribution & - & & \\
\hline & Power poles (833 leaning, 245 broken, 120 fallen) & 377851 & 2 & 2 \\
\hline & Power meters ( $158 \mathrm{~m}$ destroyed) & 42061 & 2 & 2 \\
\hline & Cross-arms (195 broken) & 212149 & 2 & 2 \\
\hline
\end{tabular}


Table 5. Continued.

\begin{tabular}{|c|c|c|c|c|}
\hline & & \multicolumn{3}{|c|}{ Vulnerability indicators } \\
\hline & & $\mathrm{V} 1$ & $\mathrm{~V} 2$ & V3 \\
\hline & & $\begin{array}{l}\text { Extent of damage } \\
\text { in Cyclone Evan (USD) }\end{array}$ & $\begin{array}{l}\text { Criticality of the } \\
\text { service (based on a } \\
\text { predefined scale) }\end{array}$ & $\begin{array}{l}\text { Capacity of the service } \\
\text { providing authority to } \\
\text { repair damaged infrastructure }\end{array}$ \\
\hline & Weight of indicator & 1 & 1 & 1 \\
\hline \multirow[t]{2}{*}{ Infrastructure system } & Infrastructure node & & & \\
\hline & Power lines ( $6.7 \mathrm{~km}$ needing replacement) & 640658 & 2 & 2 \\
\hline \multirow[t]{3}{*}{ Power supply } & Transformers ( 25 destroyed) & 191974 & 2 & 2 \\
\hline & Radio network (destroyed) & 183684 & 2 & 2 \\
\hline & Total damage/avg criticality and capacity & 16793640 & 1.62 & 1.46 \\
\hline \multirow{5}{*}{ Land transportation } & Partially damaged roads & 5746360 & 1 & 2 \\
\hline & Fully destroyed roads & 16565614 & 1 & 2 \\
\hline & Bridges & 3632149 & 2 & 1 \\
\hline & Other infrastructure & 43860 & 1 & 1 \\
\hline & Total damage/avg criticality and capacity & 25987982 & 1.25 & 1.50 \\
\hline
\end{tabular}

was used. This was done to ensure that a high index value always indicates high vulnerability.

The results of the vulnerability assessment of Samoa's key infrastructure systems suggest that land transportation is the most vulnerable infrastructure sector of Samoa based on damage assessment. The damage cost of this sector is almost double that of the power supply sector and 7 times higher than the water supply sector. Although stakeholders considered sewerage the most critical of the infrastructure services, its comparatively lower damage cost and the higher capacity of the local authority to fix any damage, make it the least vulnerable infrastructure sector. Even after having a lower damage cost than the power supply sector, the water supply sector was ranked more vulnerable than the power supply. This is mainly because water supply infrastructure is regarded as more critical than power supply by the stakeholders. Thus our focus on vulnerability assessment was for the water sector only. Further details of the sectors' vulnerabilities follow in the sections below.

\subsection{Water supply sector}

The Samoa Water Authority (SWA), a publicly traded body, is the major water service provider in Samoa. Its water service networks cover the urban and rural regions of Upolu, Savaii and Manono Islands. A number of people, however, receive their water supply exclusively from wells, springs and rainwater reservoirs. With fewer skilled professionals in rural areas, it is frequently difficult to maintain these private water supply systems.

The Alaoa water treatment plant has the third highest customer base and is the most exposed of the water supply infrastructure network. During Cyclone Evan, it suffered
USD 2.3 million worth of damage. Stakeholders also suggested it to be very a critical asset. Therefore, this is one of the most vulnerable infrastructure components of the water supply system. Other water treatment plants of Tafitoala, Tiavi and Malololelei are also exposed, and incurred almost USD 0.5 million damage during Cyclone Evan. However, the number of people served by these treatments plants is not as high as Alaoa. On the other hand, Fuluasou and Fuluasou water treatment plants have the highest number of users (3900 and 2779, respectively) and are less exposed (the damage during Evan was comparatively lower).

Most of the water supply infrastructure was originally constructed by local villages and consist of above-ground pipe work that has been put together with whatever fittings, tools and pipes were available at the time of construction. The alignment of pipe work typically follows the river, making the pipes highly vulnerable to natural disasters.

\subsection{Sewerage system}

About $89 \%$ of the population in Samoa has access to improved sanitation facilities (GoS, 2011). Quality of water is the main driver of sanitation in every settlement. Water quality is affected by poor sanitation, stagnation and sedimentation. Heavy rainfall and inadequate drainage mean that flooding is a frequent problem, compounded by land filling and the blocking of drains. Intense flooding causes breaking of the sewerage pipes and the contaminated water spills out to the surface, which poses a public health risk as seepage and latrine runoff contaminate supplies.

Samoa's sewerage system was ranked as the least vulnerable infrastructure system among the four considered in this study. Sanitation systems located at urban Apia seem most 
Table 6. Vulnerability matrix for the 4-infrastructure system considered in this study.

\begin{tabular}{|c|c|c|c|}
\hline \multirow[t]{2}{*}{ Infrastructure system } & \multicolumn{3}{|c|}{ Indicator values for the whole system } \\
\hline & $\begin{array}{l}\text { V1 - aggregated damage } \\
\text { for all infrastructure } \\
\text { component of the system }\end{array}$ & $\begin{array}{l}\mathrm{V} 2 \text { - average criticality } \\
\text { of the infrastructure } \\
\text { component of the system }\end{array}$ & $\begin{array}{l}\mathrm{V} 3 \text { - average repair capacity } \\
\text { of the infrastructure } \\
\text { component of the system }\end{array}$ \\
\hline Water supply & 3708415 & 2.2 & 2 \\
\hline Sewerage & 4329474 & 3.0 & 1.0 \\
\hline Power supply & 16793640 & 1.62 & 1.46 \\
\hline Land transportation & 25987982 & 1.25 & 1.50 \\
\hline
\end{tabular}

Table 7. Vulnerability indices.

\begin{tabular}{lccccc}
\hline \multirow{2}{*}{ Infrastructure system } & \multicolumn{3}{c}{ Normalized indicators } & Index & Rank \\
\cline { 2 - 4 } & V1 & V2 & V3 & & \\
\hline Water supply & - & 54.3 & 65 & 119.3 & 3 rd \\
Sewerage & 2.8 & 100 & - & 102.8 & 4 th \\
Power supply & 58.7 & 20.9 & 100 & 179.6 & 2nd \\
Land transportation & 100 & - & 97.5 & 197.5 & 1 st \\
\hline
\end{tabular}

exposed to the climatic hazards as the maximum amount of damage occurred in this area during Evan. On the other hand, although North West Upolu has the maximum number of properties with private sanitation systems, this area had comparatively less damage during Evan.

Vulnerability of off-site sanitation seems to be low as there was no damage reported from the SWA-managed WTP in Sogi, though two wastewater pump stations at Aggie Grey's Hotel were reported to be completely destroyed (GoS, 2013b). Only minimal damage was reported at the sludge treatment facility at Tafaigata and the two public toilet facilities in Sogi and Eleele-fou, though both facilities were closed down following the cyclone due to lack of water supply.

One thing that should be noted is that stakeholders identified the sanitation and sewerage system as the most critical infrastructure. However, the repair capacity of the local authority of such infrastructure is very high. Comparatively lower damage cost and higher repair capacity resulted in comparatively lower vulnerability of the sanitation and sewerage system than the other three sectors of Samoa.

\subsection{Power supply sector}

The country has been producing $12 \mathrm{MW}$ of electricity through renewable resources, which is $29.27 \%$ of its total capacity (World Bank, 2010). Electricity generation on Upolu is a mix of diesel and hydropower generation. The main diesel power station on Upolu is located at Tanugamanono. The remaining hydropower capacity comes from four run-of-river schemes (with a combined installed capacity of $4.5 \mathrm{MW}$ ) and one scheme with a reservoir. In general, cyclone damage and continuing land clearance were the ma- jor threats affecting the ability of water catchment areas to hold water as well as generate power in Samoa. These are exaggerated by the extreme heavy rainfall and subsequent flooding, which in turn causes extensive erosion.

Overall, the power sector of Samoa was ranked as the second most vulnerable sector. High exposure of the distribution and transmission system, and moderate criticality and repair capacity of the local authority, contributed to such high vulnerability. Following Cyclone Evan in 2012, the entire island of Upolu and part of Savai'i were without power. Within one week, power was restored to approximately $10 \%$ of the population of Upolu, and within four weeks, about $60 \%$ were reconnected. Full reconnection was achieved by mid-February 2013. This suggests that the repair capacity of the power sector is relatively higher than the other sectors, which was also reflected in the stakeholders' response through the V3 of the vulnerability model of this study. On the other hand, power transmission infrastructure is stated to have partial repair capacity, which made them more vulnerable under a climatic hazard than the power generation infrastructures. Cyclone Evan caused significant damage to three hydropower plants (Samasoni, Alaoa and Fale ole Fee) and minor damage to two additional hydropower plants. The cyclone also damaged Upolu's main Tanugamanono diesel power station.

\subsection{Land transport}

Samoa's transport sector includes all modes of transport, including air, sea and land. In this study only land transport was considered. The two main islands are well served by tarsealed ring roads and cross-island roads. Samoa's geographically compact nature and its road and shipping network make transport between and within islands relatively easy, thus facilitating access to centralized government services. Approximately $70 \%$ of Samoa's population lives within 1 kilometer of the coast, and critical infrastructure (hospitals, schools, places of employment, tourist infrastructure, port facilities, power plants, airports and roads) are located primarily in the coastal zone where roads are extremely important.

Samoa's road network faces a range of vulnerability issues (GoS, 2013b), as follows: 
- coastal exposure to sea-level rise, storm surge and wave action during cyclones and tsunamis

- inland flooding and landslides during extreme rainfall events

- damage from earthquakes

- accelerated pavement deterioration due to extreme weather and rising water tables in some locations.

In general, Samoa's land transport sector was ranked as the most vulnerable of the infrastructure sectors but our focus was on the water sector for vulnerability assessment. High exposure of roads and bridges and their associated damage costs are the prime reason behind such a high vulnerability ranking. Cyclone Evan caused about USD 22 million worth of damage to roads and USD 3.6 million to bridges. Criticality of the bridges is high and their repair is also very costly and time-consuming.

\section{Discussion}

Among other vulnerabilities, water-induced vulnerabilities are major threats to the population of Samoa. Many studies (i.e., NDMP, 2006-2009; FMAP, 2007-2013) indicate that floods as a result of heavy rain are ranked as a high risk event for the country. Many coastal areas and river basins worldwide are flood-prone due to heavy rainfall and cyclonic storm surges. Keeping the risk of flooding at an acceptable level is an ongoing challenge. Nowadays the range of options to mitigate flood risk is becoming more diverse, varying from nonstructural measures, such as early warning systems and zoning, to traditional structural measures, such as levees, dams, flood detention areas and pumping stations. The impact of structural measures on natural processes is large and often results in undesirable side effects, such as land subsidence or disturbance of ecosystem functioning and a loss of ecosystem services, with large consequences for local communities.

Considering the above rationale, we emphasize the need to strengthen Samoa's water supply sector, particularly with reference to the Integrated Water Management Plan (IWMP) for the five catchments in the Apia area. Adaptation should not be understood as simply implementing the correct technology or practice. It should be part of a coherent, intersectoral strategy to reduce climate risk and maintain sustainable water resources. IWMP is a strategy recommended here that provides an overall decision-making framework for climate change adaptation in water resources through mainstreaming climate adaptation into its plans. To address the issue of climate risks, the IWMP should include a vulnerability and adaptation assessment. An adopted IWMP will enable the government of Samoa to strengthen the overall water management plan by considering future climate risk and "ridge to reef" approaches.
"Ridge to reef" is a wide concept and may need to be covered in a separate paper. The time has come to take a fresh look at the future of our coastal zones by integrating water resources and balancing economic development, conservation and adaptation to inevitable change. Re-examination of system scales and adoption of the "ridge to reef" approach offers real perspectives for finding a way forward. Therefore, the potential of more nature-based flood defense solutions, such as oyster reefs, salt marshes and mangroves, that are thought to not have such negative effects on the natural environment, is actively being explored. Studies should explore the application of nature-based defenses and integrating water, coastal and livelihood-based defenses.

The results suggest only the relative vulnerability of the four infrastructure systems of Samoa, not the vulnerability of each individual infrastructure component due to the lack of data. Thereafter many others factors hinder the vulnerability assessment, such as the way the study was designed and implemented using information collected from existing reports; therefore the quality of results of this study is highly dependent on the quality of those reports. Damage to infrastructure was modeled using the reported damage data on Cyclone Evan. An ideal vulnerability study would require a physical hazard mapping of areas under investigation of such a coastal flooding event. However, such a detailed assessment of physical climate risk for Samoa was neither readily available nor within the scope of this report. Therefore, this study adopted the damage caused by Cyclone Evan as a proxy to such investigative work. It can be argued that the use of actual damage data instead of model-based risk assessment data can provide a more realistic approach to the problem. An indicator-based model was used for the vulnerability assessment. Indicators were selected in collaboration with stakeholders in order to make sure that they are relevant for the local context. However, there is a possibility that the study might have missed some other relevant key processes that define the vulnerability of the Samoan infrastructure system. The results suggest only the relative vulnerability of the four-infrastructure system of Samoa, not the vulnerability of each individual infrastructure component.

\section{Conclusion}

This paper studied the existing available data and reports to assess climate-related vulnerability of four major infrastructure sectors on Samoa. An indicator-based vulnerability model, SIVM, was developed for this purpose. A range of stakeholders was consulted both at the model development and data collection stages. The study identified some of the critical infrastructure components of each sector and collected data on the vulnerability indicators for each of the sectors. The resulting vulnerability index suggests that the transportation sector is the most vulnerable among the four sectors considered in this study. High physical exposure and 
comparatively lower capacity to repair the transport infrastructure, such as bridges, accounted for the high vulnerability. The power sector of Samoa was ranked as the secondmost vulnerable sector, mainly because of the high physical exposure of the power generation and distribution system. The water supply sector was ranked third. Some of the water supply infrastructure, such as the Alaoa, Tafitoala and Tiavi water treatment plants, were rated as very critical; they play a key role in maintaining safe water supply for public use. The sewerage system was ranked the least vulnerable sector. The sewerage system of Samoa is mainly composed of individual household latrines, which are comparatively easy to repair locally. Based on the results of this vulnerability assessment, a list of adaptation options and their possible outcomes were developed through consultation with the government of Samoa. Therefore, considering the current gaps and vulnerabilities of key infrastructure, this report proposes developing a "ridge to reef" integrated watershed management plan for the greater Apia area. 


\section{Appendix A}

Table A1. List of stakeholders interviewed.

\begin{tabular}{|c|c|c|}
\hline Organization & Name & Designation \\
\hline MNRE & Taulealeausumai L. Malua & CEO \\
\hline MOF & $\begin{array}{l}\text { Tupaimatuna I Lavea } \\
\text { Noumea Simi } \\
\text { Litara Taulealo }\end{array}$ & $\begin{array}{l}\text { CEO } \\
\text { ACEO Aid \& Debt Management } \\
\text { PPCR Coordinator }\end{array}$ \\
\hline MNRE & Malaki Iakopo & Principal WRD Officer \\
\hline MNRE, MOF, MWCSD & $\begin{array}{l}\text { Filomena Nelson } \\
\text { Lita Lui } \\
\text { Sulu Amataga } \\
\text { Fiasosoitamalii Siaosi } \\
\text { Josephine Stowers-Fiu } \\
\text { Andrew Riplinger } \\
\text { Rosa Toese-Siaosi } \\
\text { Lameko Osana } \\
\text { Mulipola A Titimaea } \\
\text { Malaki Iakopo }\end{array}$ & $\begin{array}{l}\text { ACEO DMO } \\
\text { Principal Aid Officer } \\
\text { ACEO } \\
\text { WRD } \\
\text { WRD } \\
\text { ACEO Legal } \\
\text { Fulbright } \\
\text { Sector Coordinator } \\
\text { WRD } \\
\text { ACEO Meteorology } \\
\text { WRD - PRO }\end{array}$ \\
\hline $\begin{array}{l}\text { MNRE (PUMA, WRD, } \\
\text { Land Management, Land } \\
\text { Technical Services) }\end{array}$ & $\begin{array}{l}\text { Suluimalo Amataga Penaia } \\
\text { Malaki Iakopo } \\
\text { Pau Ioane }\end{array}$ & $\begin{array}{l}\text { ACEO WRD } \\
\text { Principal WRD Officer } \\
\text { Principal LTS Officer }\end{array}$ \\
\hline $\begin{array}{l}\text { MWTI } \\
\text { LTA } \\
\text { MNRE (PUMA) }\end{array}$ & $\begin{array}{l}\text { Leasi Galuvao } \\
\text { Seimaleula Sinapati Ulberg } \\
\text { Ferila Brown }\end{array}$ & $\begin{array}{l}\text { LTA CEO } \\
\text { LTA ACEO Procurement \& Planning } \\
\text { PUMA Acting ACEO }\end{array}$ \\
\hline $\begin{array}{l}\text { MAF } \\
\text { MWCSD } \\
\text { MCIL } \\
\text { STA }\end{array}$ & $\begin{array}{l}\text { Rosa Toese Mene } \\
\text { Salote Meredith } \\
\text { Amiafolau Afamasaga }\end{array}$ & $\begin{array}{l}\text { MWCSD Community Sector Coordinator } \\
\text { MCIL Trade Sector Coordinator } \\
\text { STA Climate Change Coordinator }\end{array}$ \\
\hline
\end{tabular}


Acknowledgements. This paper has been prepared based on the Samoa infrastructure vulnerability assessment to support the UNDP GEF funded project "Economy-wide integration of climate change adaptation and DRM/DRR" to reduce vulnerability in Samoan communities, with financial support from USAID Climate Change Adaptation Project Preparation Facility for Asia and The Pacific (USAID Adapt Asia-Pacific).

Edited by: J. Brown

Reviewed by: two anonymous referees

\section{References}

Adger, W. N.: Social vulnerability to climate change and extremes in coastal Vietnam, World Dev., 27, 249-69, 1999.

Adger, W. N. and Kelly, P. M.: Social vulnerability to climate change and the architecture of entitlements, Paper presented at IPCC Workshop on Adaptation to Climatic Variability and Change, San Jose, Costa Rica, 29 March-1 April 1998.

Babel, M. S., Pandey, V. P., Rivas, A. A., and Wahid, S. M.: Indicator-based approach for assessing the vulnerability of freshwater resources in the Bagmati River Basin, Nepal, Environ. Manage., 48, 1044-1059, doi:10.1007/s00267-011-9744-y, 2011

Bankoff, G., Frerks, G., and Hilhorst, D. (Eds.): Mapping Vulnerability: Disasters Development and People, Earthscan, London, 2004.Barnett, J. and Adger W. N.: Climate change, human security and violent conflict, Polit. Geogr., 26, 639-655, 2007.

Birkmann, J.: Risk and vulnerability indicators at different scales: applicability, usefulness and policy implications, Environ. Hazards, 7, 20-31, 2007.

Blaikie, P., Cannon, T., Davis, I., and Wisner, B.: At Risk: Natural Hazards, People's Vulnerability and Disasters, Routledge, London, 127-133, 1994.

Burton, I. and White, G. F.: The Environment as Hazard, The Guilford Press, New York, 31-60, 1993.

Cannon, T.: Vulnerability analysis and the explanation of natural disasters, in: Disasters Development and Environment, edited by: Varley, A., John Wiley, Chichester, 13-30, 1994.

Cannon, T.: Vulnerability analysis, livelihoods and disasters, in: Risk 21: Coping with Risks Due to Natural Hazards in the 21st Century, edited by: Ammann, W. J., Dannenmann, S., and Vulliet, L., Taylor and Francis Group, London, UK, 41-49, 2006.

Cannon, T., Twigg, J., and Rowell, J.: Social Vulnerability, Sustainable Livelihoods and Disasters, DFID, London, 69 pp., 2003.

Climate Risk Profile for Samoa, report prepared by Young, W. J., Samoa Meteorology Division, Government of Samoa, available at: http://www.sprep.org/att/IRC/eCOPIES/Countries/ Samoa/7.pdf (last access: 14 June 2013), 2007.

Cutter, S. L.: The vulnerability of science and the science of vulnerability, Ann. Assoc. Am. Geogr., 93, 1-12, 2003.

Dercon, S.: Assessing Vulnerability to Poverty, UK Department for International Development, Oxford University, London, 124136, 2001.

Dercon, S.: Income risk, coping strategies and safety nets, World Bank Res. Obser., 17, 141-66, 2002.

Dercon, S.: Vulnerability: a micro perspective, in: Securing Development in an Unstable World, edited by: Bourguignon, F.,
Pleskovic, B., and van der Gaag, J., World Bank Publications, Washington, D.C., USA, 117-146, 2006.

Dilley, M.: Setting priorities: global patterns of disaster risk, Paper of the Scientific Discussion on Extreme Natural Hazards, Royal Society, 26-27 October 2005, London, p. 12, 2005 (unpublished).

Downing, T. E.: Assessing Socioeconomic Vulnerability to Famine: Frameworks, Concepts and Applications, Research Report 911, World Hunger Program, Brown University, Providence, RI, 1991.

Eakin, H. and Luers, A. L.: Assessing the vulnerability of socialenvironmental systems, Annu. Rev. Environ. Resour., 31, 365394, 2006.

Ebert, U. and Welsch, H.: Meaningful environmental indices: a social choice approach, J. Environ. Econ. Manage., 47, 270-283, 2004.

Füssel, H.-M. and Klein, R. J. T.: Climate change vulnerability assessments: an evolution of conceptual thinking, Climatic Change, 75, 301-329, 2006.

Gbetibouo, G. A., Ringler, C., and Hassan, R.: Vulnerability of the South African farming sector to climate change and variability: an indicator approach, Nat. Resour. Forum, 34, 175-187, doi:10.1111/j.1477-8947.2010.01302.x, 2010.

Government of Samoa (GoS): Coastal Infrastructure Management Plan: Apia District - Implementation Guidelines, 2007.

Government of Samoa (GoS): Second National Communication to the UNFCC, 2010.

Government of Samoa (GoS): Samoa National Infrastructure Strategic Plan, Government of Samoa, Apia, Samoa, 2011.

Government of Samoa (GoS): SAMOA: Technical Evaluation of the Tafitoala Village Coastal Defence, Report 3 - Updating the Draft Vulnerability and Adaptation (VA) Report, Samoa, SPREP, 2013a.

Government of Samoa (GoS): SAMOA: Post-Disaster Needs Assessment, Cyclone Evan, 2012, Apia, Samoa, 2013b.

Hoegh-Guldberg, O. and Bruno, J. F.: The impact of climate change on the world's marine ecosystems, Science, 328, 1523-1528, 2010.

Ibarraran, M. E., Malone, E. L., and Brenkert, A. L.: Climate Change Vulnerability and Resilience', Environment, Development and Sustainability, 12, 365-388, 2010.

Ionescu, C., Klein, R. J. T., Hinkel, J., Kumar, K. S. K., and Klein, R.: Towards a Formal Framework of Vulnerability to Climate Change, NeWater Working Paper 2, Potsdam Institute for Climate Impact Research, Potsdam, 2005.

IPCC: Climate Change 2001: Impacts, Adaptation and Vulnerability, in: Contribution of Working Group II to the Fourth Assessment Report of the Intergovernmental Panel on Climate Change, edited by: McCarthy, J. J., Canziani, O. F., Leary, N. A., Dokken, D. J., and White, K. S., Cambridge University Press, Cambridge, UK, 273-313, 2001.

IPCC: Contribution of Working Group II to the Fourth Assessment Report of IPCC on Climate Change, Impacts, Adaptations and Vulnerability, Cambridge University Press, p. 976, 2007.

IPCC: Climate Change 2013: The Physical Science Basis, in: Contribution of Working Group I to the Fifth Assessment Report of the Intergovernmental Panel on Climate Change, edited by: Stocker, T. F., Qin, D., Plattner, G.-K., Tignor, M., Allen, S. K., Boschung, J., Nauels, A., Xia, Y., Bex, V., and Midgley, P. M., 
Cambridge University Press, Cambridge, UK, New York, NY, USA, 1535 pp., 2013.

Kasperson, R. E., Dow, K., Archer, E., Caceres, D., Downing, T., Elmqvist, T., Eriksen, S., Folke, C., Han, G., Iyengar, K., Vogel, C., Wilson, K., and Ziervogel, G.: Vulnerable people and places, in: Ecosystems and Human Wellbeing: Current State and Trends, vol. 1, edited by: Hassan, R., Scholes, R., and Ash, N., Island Press, Washington, D.C., 143-164, 2005.

McCarthy, J. J.: Climate Change 2001: Impacts, Adaptation, and Vulnerability: Contribution of Working Group II to the Third Assessment Report of the Intergovernmental Panel on Climate Change, Cambridge University Press, p. 845, 2001.

Mearns, M., Leach, M., and Scoones, I.: Environmental entitlements: A framework for understanding the institutional dynamics of environmental change, Discussion Paper 359, Institute of Development Studies, University of Sussex, Brighton, UK, 1997.

Moser, C. O. N.: The asset vulnerability framework: reassessing urban poverty reduction strategies, World Dev., 26, 1-19, 1998.

Moss, R. H., Brenkert, A. L., and Malone, E. L.: Vulnerability to Climate Change: A Quantitative Approach, PNNL-SA-33642, Pacific Northwest National Laboratory, Richland, Washington, 2001.

O'Keefe, P., Westgate, K., and Wisner, B.: Taking the naturalness out of natural disasters, Nature, 260, 566-567, 1976.

Pelling, M.: The Vulnerability of Cities: Natural Disasters and Social Resilience, London, Routledge, 1-26, 2003.

Platteau, J. P.: Traditional systems of social security and hunger insurance: past achievements and modern challenges, in: Social Security in Developing Countries, edited by: Ahmad, E., Dreze, J., Hills, J., and Sen, A., Clarendon, Oxford, 112-170, 1991.

Preston, B. L., Smith, T. F., Brooke, C., Gorddard, R., Measham, T. G., Withycombe, G., and Abbs, D.: Mapping Climate Change Vulnerability in Sydney Coastal Council Group, available at: http://www.csiro.au/resources/ SydneyClimateChangeCoastalVulnerability.html (last access: 19 September 2011), 2008.

Smit, B. and Pilifosova, O.: Adaptation to climate change in the context of sustainable development and equity, Sustain. Dev., 8, 9 pp., 2003.

Strategic Programme for Climate Resilience (SPCR): Prepared for the Pilot Programme for Climate Resilience (PPCR), February 2011, available at: http://www.climatefundsupdate. org/listing/pilot-program-for-climate-resilience (last access: 10 March 2015), 2011.
Thywissen, K.: Core terminology of disaster reduction: a comparative glossary in: Measuring Vulnerability to Natural Hazards Towards Disaster Resilient Societies, edited by: Birkmann, J., UNU Press, Tokyo, New York, Paris, 2006.

Tonmoy, F. N. and El-Zein, A.: SEVA: a non-linear mathematical framework for climate change vulnerability assessment, Paper presented at the 20th International Congress on Modelling and Simulation (MODSIM2013), 2 December 2013, Adelaide, 2013.

Tonmoy, F. N., El-Zein, A., Ghetti, I., and Massie, R.: Vulnerability to sea level rise of 8 beaches in Shoalhaven: a new multidimensional assessment methodology, Paper presented at the 21st NSW Coastal Conference, Kiama, New South Wales, Australia, 2012.

United Nations International Strategy for Disaster Reduction (UN/ISDR): Living with Risk, a Global Review of Disaster Reduction Initiatives, 2004 version, UN Publications, Geneva, 2004.

United Nations Development Programme (UNDP): Reducing Disaster Risk, a Challenge For Development a Global Report, UNDP - Bureau for Crisis Prevention and Recovery (BRCP), New York, available at: http://www.preventionweb.net/files/ 1096_rdrenglish.pdf (last access: 10 March 2015), 2004.

Webb, A. P. and Kench, P. S.: The dynamic response of reef islands to sea-level rise: evidence from multi-decadal analysis of island change in the Central Pacific, Global Planet. Change, 72, 234246, 2010.

Wisner, B.: Who?, What?, Where?, When?, in an emergency: notes on possible indicators of vulnerability and resilience: by phase of the disaster management cycle and social actor, in: Environment and Human Security: Contributions to a Workshop in Bonn, 23-25 October 2002, Bonn, Germany, edited by: Plate, E., 12/712/14, 2002.

World Bank: Economic Adaptation to Climate Change - Samoa, Washington, D.C., 22-34, 2010. 